\title{
Infinitival Verb Phrases in English and Their Translations to Czech - A Contrastive Study of Non-finite Verb Phrases in English AND CZECH FICTION
}

\author{
Renata Šimůnková \\ Technical University of Liberec, Faculty of Science, Humanities and Education, \\ Department of English Language, \\ Komenského 314/2, 46001 Liberec V-Kristiánov, Czech Republic \\ e-mail: renata.simunkova@tul.cz
}

\begin{abstract}
One of the main differences between English and Czech resides in the fact that an English sentence is much more frequently condensed by means of nominal forms. Moreover, as it has been illustrated by recent research, it is an area where both languages seem to be going through noticeable development resulting in the mentioned differences becoming even more significant. The paper presents results of a comparative study of infinitive verb phrases in English and their reflections in Czech translations. The most frequent functions of the infinitive have been its function as an object and an infinitive of purpose. Other frequent functions included a postmodification of a noun or an adjective and an infinitive after a copula verb. The most tightly corresponding form of translation was that of the infinitive of purpose which in 70 percent of cases was translated as a subordinate adverbial clause of purpose.
\end{abstract}

\section{Keywords}

Non-finite verb phrase; Infinitive; Translation, Condensation; Comparison.

\section{Introduction}

The higher degree of nominalization in English as opposed to more verbal character of Czech has been observed and repeatedly commented on since 1931 (Curme). Among Czech linguists it was mainly Wilém Mathesius who extensively studied this area and later for example Vachek [13] and Dušková [6]. The pertaining interest in English condensers and their counterparts in Czech is therefore understandable. My motivation further drew on two additional sources. First it was the finding that current studies of non-finite verb phrases both in English and in Czech seem to suggest that the recent development of this significant structural difference is in the direction of higher non-correspondence and thus comparative studies of currently used language seem even more important than before. In her research into the development of the structure of an English sentence in the last hundred years, M. Malá $[10,11]$ has discovered that the frequency of use of non-finite clauses has been increasing. On the other hand, as has been pointed out by e.g. Dvořák [7], the system of Czech non-finite forms has been getting less complex with the participle forms disappearing from active use. The second source was a study of students' translations of non-finite verb phrases conducted two years ago which demonstrated that students really had problems when translating the phrases in question. They often applied word-for-word translation using Czech "prrechodníky" (transgressives) which no longer belong among productive language means, or they used one "established" way of translation for certain structures regardless of the context and the fact that it may not have been an ideal solution for the respective context. They generally lacked experience of and opportunities for contrastive work. 
The study pursues two aims. The first one is to examine the use of non-finite phrases in contemporary English fiction and their reflection in corresponding translations. The second aim concerns the application of the results into the process of teaching. The information and contemporary authentic examples gained will be used to help students see to what extent and how the two languages structure the respective area differently.

For the first aim to be attainable, it was first necessary to establish what the subject-matter of the study actually is, namely to define what non-finite verb phrases are and how they can be classified.

\section{Theoretical Background}

Although, as it has already been mentioned, non-finite verb phrases are frequently used in English, being one of its distinguishing features, at least when compared to Czech, and their frequency even seems to be increasing, recognised English reference sources often do not pay much attention to establishing and defining them precisely. Leech and Svartvik [9, p. 413] do not define a non/finite verb phrase in any way. They just list the non-finite forms of the verb: "the infinitive, -ing participle and -ed participle". Carter and McCarthy's [5, p. 546] treatment of non-finite verb forms also seems rather limited. They do not speak explicitly about nonfinite verb forms at all. In the glossary, they only define the infinitive and participles, referring to them as non-tensed forms and just describing their form. They mention the studied area for the second time among clause types where they introduce non-finite clauses as the ones containing "a lexical verb which does not indicate tense" and they further add that "References to time (and person and number) are normally interpreted from the context or from information in the finite clause to which the non-finite clause is related", leaving out the perfect forms of non-finite verb phrases completely. The same set of non-finite phrases is also introduced by Quirk et al. [12] but even in this book the notion of the non-finite verb form or phrase is not really defined. First, on page 96, five basic verb forms are introduced with the explanation that "These verb forms have different functions in finite and nonfinite verb phrases. On this basis, the -s form and the past form are called FINITE, whereas the -ing participle and -ed participle are called NONFINITE". The matter is then discussed in greater detail on page 150 where it is stated that "The infinitive, the -ing participle, and the -ed participle are the nonfinite forms of the verb. Hence any phrase in which one of these verb forms is the first or only word is a nonfinite verb phrase. Such phrases do not normally occur as the verb phrase of an independent clause". And at [12, pp. 237-239] Quirk et al. discuss meaning in the nonfinite verb phrase claiming that "The same semantic distinctions apply to both finite and nonfinite verb phrases, in so far as the structural possibilities of the nonfinite verb phrase permit". Then they focus on important qualities of non-finite verb phrases which include the fact that they can appear in an active and passive form, and with the exception of the -ed participle, they can express "formal contrast of perfective/nonperfective and progressive/nonprogressive aspect". Examples are, therefore, provided, but the notion of the perfect infinitive, progressive infinitive, perfect participle form, etc. is not really established. Biber et al. [1, p. 99] define the verb phrase as a phrase "containing a lexical verb or a primary verb as head or main verb, either alone or accompanied by one or more auxiliaries", and they distinguish between the finite and non-finite verb phrase based on the fact that the "Non-finite verb phrases do not contain any specification of tense and modality". Although they do not provide a list of non-finite verb forms, from their classification of non-finite verb clauses [1, p. 198-201] into "infinitive clauses, ing-clauses and ed-clauses", it can be inferred that they work with the same forms as the three previously mentioned reference books. As regards the grammar of non-finite verb phrases, Biber et al. [1, pp. 90-100] first claim that 
"they have fewer possibilities of variation", list examples of possible forms: having gone, to have gone, to be caught, being caught and then they add that "Both finite and non-finite verb phrases may be marked for the perfective aspect (has gone, to have gone, etc.). Both also have passive forms (was being thanked, to be killed, etc.)". To conclude, native authors of reference materials tend not to deal with non-finite verb phrases in much a systematic way. They establish their existence, write about them, often just seeing them as counterparts or alternatives to finite verb phrases without attempting to introduce some kind of system which would enable readers to understand them in their complexity.

Czech Anglicists, on the other hand, possibly influenced by the fact that they are well aware of the differences and difficulties in this area, seem to deal with non-finite verb phrases in much bigger detail. Dušková ${ }^{1}[6$, p. 165] explains that

"According to the fact whether the verb form expresses all verb categories or only
some of them, the verb forms are divided into finite and non-finite. Finite verb
phrases express grammatical concord with a subject in the person and number
while non-finite verb phrases do not distinguish the person and number. As
regards other verbal categories, only the system of gender and partly the
temporal system are applied in non-finite verb phrases."

For our purpose, a non-finite phrase will be a verb phrase which is not marked for tense and subject-verb concord.

Having established what non-finite forms are, the next logical step is discussing their classification, determining what non-finite verb forms will be distinguished in the study. Across the recognized reference materials, there are two non-finite verb forms which are indisputable: the infinitive and the past participle (which is however sometimes referred to as -ed participle or -en participle). These two forms are distinguished in e.g. Qiurk [12], Biber [1], Leech and Svartvik [9], Dušková [6], etc. and they are also defined in the same way. Where, however, there does not seem to be much consent, is the area of -ing forms. Some authors $[12,1,9]$ speak about -ing clauses, not distinguishing them any further. However, for example Quirk et al. [12] distinguish in detail between -ing participle verbs and adjectives on the one hand and -ing nouns on the other. Yet they do not distinguish formally (only in terms of function) between for example the following two clauses, referring to both as ing-clauses: "My having had what I describe as a mental image of Charlotte Street was necessitated ..." and "It is customary to ignore the latter effect when discussing resonance". Other authors, e.g. Dušková [6], establish a special category of the gerund (which in fact corresponds to a big extent to Biber's ing-noun), an -ing form functioning as a noun, as distinctive from the present participle, which is closer to an adjective. She further distinguishes the gerund from a deverbal noun, which has typically nominal features, while in the gerund also some verbal features can be observed, e.g. complementation by an object, postmodification by an adverbial or active/passive voice distinction.

Regardless of the terminology used, most authors arrive at the need to distinguish between the two ends of the scale/gradient of the non-finite -ing form functions (nominal and verbal) at some point, and we thus believe that it is also logical to distinguish between the non-finite clauses formed with -ing verb forms in these two functions. We will therefore work with the category of the gerund as a distinctive non-finite verb form and will also distinguish gerund

\footnotetext{
${ }^{1}$ Translated by the author. The original wording was as follows: Podle toho, zda slovesný tvar vyjadřuje všechny slovesné kategorie nebo jen některé $\mathrm{z}$ nich, se slovesné tvary dělí na určité a neurčité. Určité slovesné tvary vyjadřují gramatickou shodu s podmětem v osobě a čísle, kdežto neurčité (infinitiv, gerundium, participium) osobu a číslo nerozlišují. Z ostatních slovesných kategorií se u neurčitých slovesných tvarů uplatňuje pouze systém rodový a zčásti systém temporální (v češtině též kategorie vidu).
} 
clauses in addition to -ing participle (or present participle) clauses. In our classification thus the two examples of non-finite clauses introduced in the previous paragraph would be classified as a non-finite clause in the form of the gerund and a non-finite clause in a form of the present participle, respectively. To conclude this section, in our study the following nonfinite verb forms will be distinguished: the infinitive, gerund, present participle and past participle and their respective forms: passive, progressive or perfect.

\section{$3 \quad$ Methods and Procedures Applied}

In order to meet the aims above, the study was conducted in several steps or stages. First, it was necessary to find suitable books to be used as sources of excerpts based on which a parallel corpus was compiled. Then the excerpted non-finite phrases were classified according to the predetermined functions, within each group the corresponding translations were collected, and the results were quantitatively and partly also qualitatively analysed.

\subsection{Corpus Compilation}

With regards to the developments both in English and Czech mentioned in the Introduction, it was crucial to use sources as contemporary and possible. Therefore, only books not older than 15 years were selected. To ensure the quality of translation, only translations which were awarded recognized translation prizes were included in the corpus, e.g. the Josef Jungmann Prize or Award for Creativity (Tvưrčí cena). The four selected books actually used are [1421]. The second step was to compile a corpus of non-finite forms and their corresponding translations. For the purpose of quantitative comparison and comparison with regard to individual authors, 200 non-finite verb phrases were excerpted from each book. Each excerpt however always represented a whole sentence which included the respective non-finite phrase to allow for subsequent qualitative discussions. The excerpted non-finite forms were also tagged so that filtering according to particular criteria was then possible. The following pieces of information were marked: author/book, type of the non-finite forms (passive and perfect forms of individually distinguished types (see above) were marked separately), way of translation into Czech. The potential ways of translation were investigated in literature prior to the compilation of the corpus to enable these categories to be marked so that the corpus could be filtered according to the way of translation in the future. This preliminary theoretical classification was then adjusted based on the actual translations appearing in the corpus (however, really only slight adjustments were needed and only in the area of translations of present participle forms which are not further focused on in this paper).

\subsection{Analysis of the Excerpts}

The corpus used for the study contained 800 non-finite phrases and their corresponding translations. In terms of the infinitive, two basic forms were distinguished, present and perfect infinitive, both further marked for passive or progressive form, if they have appeared. The bare infinitive was not treated separately as its distinction from the regular/full form of the infinitive is purely grammatical, not influencing the function or the meaning of the form. Next the basic functions of the infinitive were established, the first five are based on Dušková [6, pp. 542-569] and the last one has been added inspired by Quirk [12] or Biber [1]. Although included in the overall quantitative analysis, the infinitive functioning as a direct object of a transitive verb has been excluded from further analysis as in terms of translation the two languages closely correspond and therefore this function does not represent any challenge or difficulty and Czech learners of English are confident in its use. This has also been confirmed by the study conducted by Hornová [8, p. 49], who has studied the use of non-finite verb forms in various functions by university students of English (a similar target group as ours) 
and has discovered that "The statistical data about the object position of the infinitive in the corpus are closer to the LGSWE corpus findings and the total number of 414 is more or less evenly distributed among all the pairs of students". In our study, therefore, the functions of the infinitive listed below have been distinguished and for better comprehension, each function is illustrated by an example taken from the corpus.

1) Infinitive after a copula verb (And indeed, were he to remember it he might well be wary. [18])

2) Infinitive as a nominal sentence element (It was always my greatest ambition to see Shakespeare on stage, but there is no theatre between here and New York City, hopelessing my wish. [20])

3) Infinitive as a postmodifier of a noun (Why so certain there'll still be a Company to pay us in five years' time? [18])

4) Infinitive as a postmodifier of an adjective (Too wet to work in garden. [16])

5) Infinitive as an adverbial (... three minutes and more to run through its length. [14])

6) + independent comment (Exceeding well worded, to speak plain. [14])

Regarding the Czech translations, the following categories were distinguished:

1) Infinitive

2) Main clause

3) Subordinate clause

4) Different solution

5) Not translated - omitted

Originally one more category had been considered and it was translation by means of a noun, mainly deverbal noun. Such a way of translation is included and discussed for example in Dušková [6, pp. 555-556]: "He forbade me to use his typewriter. Zakázal mi používání svého psacího stroje. or She forced herself to concentrate. Přinutila se k soustředění."

No such case, however, appeared in the corpus and therefore this category was not established and marked.

\section{Discussion of the Results}

Our discussion starts with the overall distribution of the non-finite verb forms found in the corpus. They are summarised in Table 1 where the first column presents the particular book and the following columns present the absolute quantities of each individual form found in each individual book.

Tab. 1: Non-finite forms: quantitative summary

\begin{tabular}{|l|c|c|c|c|}
\hline Book & Infinitive & Gerund & Present participle & Past participle \\
\hline [14] Enright & $74 / 42$ & 29 & 49 & 48 \\
\hline [16] Harding & $77 / 41$ & 21 & 53 & 49 \\
\hline [18] Barnes & $69 / 37$ & 36 & 57 & 38 \\
\hline [20] Mitchell & $85 / 53$ & 31 & 39 & 39 \\
\hline
\end{tabular}

Source: Own

Participle forms, if treated together, represented the most frequently occurring form. If taken separately, then the highest frequency was reached by the infinitive, followed by the present and past participle with the gerund being generally the least frequent. 
The most surprising information gained from this overall summary has been the fact that in the whole corpus not a single perfect form has been found. The first obvious source to consult this finding was Biber et al. and their Longman Grammar of Spoken and Written English [1], which is a grammar based on a corpus providing information on frequencies of various grammatical phenomena and forms. However, as it has been discussed earlier, non-finite forms as such have not been given any really systematic attention and as regards the perfect forms themselves, only their mere existence was mentioned, and although a number of examples of infinitive clauses and ing-clauses are provided, the perfect forms are not included. Therefore, also no information regarding their frequencies has been found. Other resources have been searched for to acquire some explanation but with only little success. Our findings can at least be considered as corresponding to the results of Bowie and Aarts [3], who in their article Change in the English infinitival perfect construction have come to a conclusion that the perfect infinitive is mainly used as a part of complex verb phrases (modal verb phrases, perfect tenses) and significantly less frequently as a condenser. Moreover, the overall frequency of this form seems to be decreasing, from $5.75 \%$ in the period of the $1950 \mathrm{~s}-$ 70 s to $0.67 \%$ in the 1990 s. The best source to check would naturally be a corpus. This will, however, be a subject-matter of future investigations.

The remaining part of the article will focus on the infinitive forms only. Tables $2-5$ present the distribution of the established functions of the infinitive in the individual books (the left hand column) and the ways in which they were translated into Czech (the right hand column).

Tab. 2: The infinitive in Enright [14-15]

\begin{tabular}{|l|r|l|r|}
\hline Function of infinitive & Number & Form of translation & Number \\
\hline Part of the verb after copula & 2 & Infinitive & 12 \\
\hline Noun phrase & 0 & Main clause & 5 \\
\hline Postmodification of a Noun & 10 & Subordinate clause & 23 \\
\hline Postmodification of Adjective & 7 & Different solution & 2 \\
\hline Adverbial & 23 & Not translated - omitted & 0 \\
\hline Comment & 0 & & \\
\hline Total number & $\mathbf{4 2}$ & Total number & $\mathbf{4 2}$ \\
\hline
\end{tabular}

Source: Own

Tab. 3: The infinitive in Harding [16-17]

\begin{tabular}{|l|r|l|r|}
\hline Function of infinitive & Number & Form of translation & Number \\
\hline Part of the verb after copula & 4 & Infinitive & 11 \\
\hline Noun phrase & 2 & Main clause & 7 \\
\hline Postmodification of a Noun & 7 & Subordinate clause & 17 \\
\hline Postmodification of Adjective & 11 & Different solution & 4 \\
\hline Adverbial & 13 & Not translated - omitted & 2 \\
\hline Comment & 4 & & \\
\hline Total number & $\mathbf{4 1}$ & Total number & $\mathbf{4 1}$ \\
\hline
\end{tabular}

Source: Own 
Tab. 4: The infinitive in Barnes [18-19]

\begin{tabular}{|l|r|l|r|}
\hline Function of infinitive & Number & Form of translation & Number \\
\hline Part of the verb after copula & 5 & Infinitive & 11 \\
\hline Noun phrase & 0 & Main clause & 4 \\
\hline Postmodification of a Noun & 9 & Subordinate clause & 10 \\
\hline Postmodification of Adjective & 6 & Different solution & 7 \\
\hline Adverbial & 17 & Not translated - omitted & 5 \\
\hline Comment & 0 & & \\
\hline Total number & $\mathbf{3 7}$ & Total number & $\mathbf{3 7}$ \\
\hline
\end{tabular}

Source: Own

Tab. 5: The infinitive in Mitchell [20-21]

\begin{tabular}{|l|r|l|r|}
\hline Function of infinitive & Number & Form of translation & Number \\
\hline Part of the verb after copula & 12 & Infinitive & 15 \\
\hline Noun phrase & 5 & Main clause & 9 \\
\hline Postmodification of a Noun & 14 & Subordinate clause & 14 \\
\hline Postmodification of Adjective & 7 & Different solution & 9 \\
\hline Adverbial & 15 & Not translated - omitted & 6 \\
\hline Comment & 0 & & \\
\hline Total number & $\mathbf{5 3}$ & Total number & $\mathbf{5 3}$ \\
\hline
\end{tabular}

Source: Own

The last summative Table 6 presents the comparison of the numbers in which the individual forms appeared in the individual books. For each book the functions are ordered according to their frequency.

Tab. 6: The summary of the frequencies of the infinitive forms

\begin{tabular}{|l|r|l|r|l|r|l|r|}
\hline [14] Enright & $\mathbf{4 2}$ & {$[\mathbf{1 6}]$ Harding } & $\mathbf{4 1}$ & {$[\mathbf{1 8}]$ Barnes } & $\mathbf{3 7}$ & {$[\mathbf{2 0}]$ Mitchell } & $\mathbf{5 3}$ \\
\hline Adverbial & 23 & Adverbial & 13 & Adverbial & 17 & Adverbial & 15 \\
\hline P-m of N & 10 & P-m of Adj & 11 & P-m of N & 9 & P-m of N & 14 \\
\hline P-m of Adj & 7 & P-m of N & 7 & P-m of Adj & 6 & V after C & 12 \\
\hline V after C & 2 & Comment & 4 & V after C & 5 & P-m of Adj & 7 \\
\hline Noun Phrase & 0 & V after C & 4 & Noun Phrase & 0 & Noun Phrase & 5 \\
\hline Comment & 0 & Noun Phrase & 2 & Comment & 0 & Comment & 0 \\
\hline
\end{tabular}

P-m of N: Postmodification of a noun;

P-m of Adj: Postmodification of Adjective;

$\mathrm{V}$ after C: Part of the verb after copula

Source: Own

\subsection{Infinitive as an Adverbial}

In the following part of the analysis we will focus on Czech translations of the individual functions of the infinitive. As has been illustrated above, the most frequently occurring function of the infinitive has been as an adverbial, and altogether two kinds of adverbials have been found, namely of purpose and time. The corresponding ways of translation are summarised in Table 7. 
Tab. 7: The frequency of infinitive as an adverbial and the corresponding translations

Source: Own

\begin{tabular}{|l|l|r|l|r|}
\hline Adverbial - 68 & Purpose & $\mathbf{6 5}$ & Time & $\mathbf{3}$ \\
\hline & Subordinate clause & 49 & Subordinate clause & 3 \\
& Main clause & 6 & & \\
& Infinitive & 5 & & \\
& Different solution & 3 & & \\
& Not translated & 2 & & \\
\hline
\end{tabular}

The infinitive form used to express an adverbial of time was used only in Harding and in all the three cases in which it has occurred, it was translated by means of an adverbial clause of time.

Blithe House is a great barn, a crusty stone mansion of many rooms, so immense it takes my little brother, Giles, who is as fast of limb as he is not of wit, three minutes and more to run through its length, a house uncomfortabled and shabbied by prudence, ... [16]

The kitchen, where the stove is always burny hot, is jollied by fat Meg, our cook, smiley and elbowed in flour, often to be found flirted by John, the manservant, who seeks a kiss but is happy to make do with a floury smack. [16]
Blithe je veliká stodola, nevrlý kamenný zámek o mnoha pokojích, tak rozlehlý, že mému bratřičcku Gilesovi, jenž má tak rychlé nohy, jako má pomalé vedení, trvá přes tři minuty, než ho přeběhne nadél, je to dům, jejž ... [17]

Kuchyn̆, v niž neustále plamenně planou kamna, zveseluje tlustá Meg, naše kuchařka, usměvavá a uloktěná v mouce které často nadbíhá sluha John a mámí z ni polibek, ale je rád, když se dočká moučného mlasku. [17]

The infinitive of purpose was in $75 \%$ of cases translated by means of an adverbial clause of purpose. As it is a common way of translation, no examples are necessary. The second most frequently used option, which was however far less frequent $(0.9 \%)$, was a main clause. The translation by a main clause has been used mainly when the purpose in fact meant a subsequent activity (the first two examples). The third example illustrates restructuring of the logical connection between the clauses: in English it is a relation of purpose + action while in Czech the same is expressed as the relation of intention + consequence.

Orito clasps the foetus's mucus-smeared wrist to search for a pulse. [20]

We horse-and-trapped him to the station, John and Mrs Grouse and I, to put him on the train to New York, where he was to be met by teachers from the school. [16]

I, to assert my difference, announced that I would therefore specialize in a category which I named, with what seemed like logic to me, Rest of the World. [18]
Pak sevře hlenem obalené zápěstí plodu a snaží se nahmatat puls. [21]

Kočářili jsme s ním na nádraží, já, John a paní Grouseová, a tam jsme ho poslali na vlak do New Yorku, kde si ho méli vyzvednout učitelé ze školy. [17]

Chtěl jsem zdůraznit svou odlišnost, a tudiž jsem oznámil, že se soustředím na oblast, kterou jsem, jak mi připadalo logické, nazval Zbytek světa. [19]

The remaining ways of translation were by means of the infinitive, or the translation was omitted in Czech altogether.

... unless we simply left her body to rot in the back garden ... [18] ...pokud nechceme jednoduše nechat její tělo shnít v zahradě za domem ... [19] 
She told me that when Grandpa died,

Grandma had been 'useless' and had left her to do everything. [18]

I said yes to the doll; it was better to appear bought off, but her refusal to help me, far from discouraging me, opposited, and merely stubborned my resolve. [14]
Když prý umřel děda, babička byla úplně ,nepoužitelná ' a všechno nechala na ní. [19]

Napanenku jsem řekla ano. Bylo to lepší tvářit se, že mě uplatila, ale její odmítnutí mé ani zdaleka neodradilo a naopak zplačtilo mé odhodlání. [15]

\subsection{Infinitive as a Postmodification of a Noun}

This was the second most frequent function of the infinitive in English and its Czech translation counterparts are summarised in Table 8.

Tab. 8: The frequency of infinitive as a postmodification of a noun and the corresponding translations

Source: Own

\begin{tabular}{|l|r|}
\hline Translated as: & $\mathbf{4 0}$ \\
\hline Infinitive & 17 \\
Subordinate relative clause & 14 \\
Different solution & 5 \\
Not translated & 3 \\
Subordinate appositive clause & 1 \\
\hline
\end{tabular}

The most frequently used ways of translation have been by means of the infinitive and a relative clause.

"The unpaid servant", say the Spanish, "has the right to pay himself", and for once, Damn Me, the Spanish are right. [20]

Why so certain there'll still be a Company to pay us in five years' time? [20]

It was one of those questions it's best not to answer, for if you keep quiet, grown-ups will always go on to something else; they lack the persistence of children. [16]

\section{I don't even know what name to put on it.} [14]
Jak řikají Španělé: "Sluha, jemuž neplatí, má právo zaplatit se sám", a projednou mají ti zatracení Španěláci recht. [21]

Jak můžete vědět, že za pět let ještě bude existovat nějaká Společnost, která by nám vyplatila mzdu? [21]

Byla to jedna z těch otázek, na něž je lepší neodpovídat, nebot' když mlčite, dospělí vždycky přejdou k něčemu jinému, jelikož jim chybi vytrvalost dètí. [17]

Nevím ani, jakým jménem ji označit. [15]

The examples above clearly illustrate one feature of non-finite phrases functioning as condensers, and it is the generally loose connection between the finite and non-finite clause. In terms of their form, the two non-finite phrases above are the same: the right to pay and $a$ Company to pay, the relations are however different as the Czech counterparts provided by the same translator show. The remaining ways of translation included different structures, e.g. the use of the infinitive form but of a verb which in English was expressed by means of a noun (farewell - rozloucit), omission of the infinitive in the cases where what was expressed by the infinitive could be inferred from the previous text, the use of the finite form of the same verb, and one example of an appositive clause. 
Wanting to see her dead came more, I admit, from writerly curiosity that filial feeling; but there was a bidding farewell to be done ... [18]

So I had no faith to lose, only a resistance, which ... [16]

And in the quietness of their attention they each realised the strength of the other and the fact that neither would be the first to walk away. [14]

... to the next item, Mr de Zoet:

'Failure to have the factory's three senior officers sign the Octavia's Bills of Lading'. [20]
Ano, připouštím: to, že jsem ji chtěl vidět mrtvou, způsobila spiš zvědavost spisovatele než synovský sentiment. Ale už kvůli té své dlouhodobé podrážděnosti, kterou jsem vioči ní cítil, jsem se s ní prostě musel rozloučit ... [19]

Žádnou víru jsem tedy neměl; pouze vzdor, jenž ... [17]

A právě v tomhle mlčenlivém zaujetí si oba uvědomili sílu svého protějšku a pochopili, že ani jeden se nezvedne a neodejde jako první. [15]

$K$ dalšímu bodu, pane de Zoete: 'z nedodržení pravidla, že naložené listy Octavie měli podepsat tři nejvýše postavení úředníci faktorie’. [21]

\subsection{Infinitive as a Postmodification of an Adjective}

Another function of the infinitive found in the corpus was as a postmodification of an adjective, see the summary in Table 9.

Tab.9: The frequency of infinitive as a postmodification of an adjective and the corresponding translations

\begin{tabular}{|l|r|}
\hline Translated as: & $\mathbf{3 1}$ \\
\hline Infinitive & 12 \\
Subordinate clause of time/degree & 7 \\
Main clause & 4 \\
Different solution & 4 \\
Not translated & 4 \\
\hline
\end{tabular}

Source: Own

The first two ways of translation (by means of an infinitive form or a subordinate clause) have been predictable, so below we will just provide an example of each and we further focus only on the less predictable ones.

Dr Maeno and his midwife did their best, but were powerless to alter what Fate had decreed. [20]

We were side-by-siding on a stone bench beside the lake and I shifted myself to otherend from him, for I found his attentions annoying and was about ready to get up and leave, but then he let slip, no doubt at some mention of mine of Shakespeare, that he had seen Hamlet. [16]
Dr. Maeno a jeho porodní bába délali, co bylo v jejich silách, ale nedokázali změnit vůli Osudu. [21]

Uvedlejšili jsme se na kamenné lavičce u jezera a já se posunula na protikonec, nebot' mé jeho pozornosti otravovaly, a иžuz̆ vypadalo, že vstanu a odejdu, $k d y z ̌ m u$ uklouzlo, patrně při některé mé zmínce o Shakespearovi, že viděl Hamleta. [17]

The less predictable ways included the translations by means of a main clause, different expressions and omission. As for a main clause, it has again been applied in the cases where the action expressed by the infinitive was subsequent to the one in the previous clause. Among other solutions, also the previously mentioned ones have occurred, namely the 
infinitive form of a different verb or a finite form of the verb corresponding to the infinitive form in English. The omission was caused, apart from the implication from the previous context which has already been discussed, also by the fact that the Czech verb used included in its meaning also the meaning expressed by the English infinitive form, e.g. Czech puisobi which includes the meaning of perception / knowledge which "she gets from others / impact she has on others".

Be ready to wedge it between your mistress's teeth, otherwise she might bite off her tongue. [20]

She is too exhausted, Orito thinks, even to fear dying tonight. [20]

There was nothing in his history to prepare him for Ada Merriman. But, he was

surprised to find, he was ready for her all the same. [14]

She got her mouth into a smile, something it was always ready to do. [16]

There was nothing overpainted about her, and she would have been pleased to know that her hair was plausibly arranged ... [18]
Až vám řeknu, strčíte ho své paní mezi zuby, jinak by si mohla prekousnout jazyk. [21]

Je tak vyčerpaná, že v sobě ani nenajde sílu bát se, že dnes v noci zemře, pomyslí si Orito. [21]

Nic v jeho dosavadním životě ho nemohlo připravit na Adu Merrimanovou, nicméně, jak s údivem shledal, byl presto hotov se s ní setkat. [15]

Nařídila ústům, aby se usmála, a ta jako vždy uposlechla. [17]

Nehrála žádnými nepřirozenými barvami a určitě by ji potěšilo (vědět), že úprava jejich vlasů působi věrohodně ... [19]

\subsection{Infinitive After a Copula Verb}

As can be seen in Table 10, this function of the infinitive was translated as part of the verb, by means of the infinitive or a different solution.

Tab. 10: The frequency of infinitive after a copula verb and the corresponding translations

\begin{tabular}{|l|r|}
\hline Translated as: & $\mathbf{2 3}$ \\
\hline Part of the verb & 11 \\
Infinitive & 5 \\
Different solution & 7 \\
\hline
\end{tabular}

Source: Own

The following two examples below represent translations by means of a part of the verb and by means of an infinitive form.

And indeed, were he to remember it, he might well be wary. [20]

"How else", demands Daniel Snitker, "is a man to earn just reward for the daily humiliations we suffer from those slit-eyed leeches?" [20]
I kdyby si ji však pamatoval, stejně by se zrejmě měl na pozoru. [21]

„Jak jinak“, táže se Daniel Snitker, ,si má člověk vydobýt zaslouženou odměnu za to každodenni ponižování, které musíme snášet od těch šikmookých pijavic? " [21]

The following translations are less predictable applying non-standard solutions. In all the cases, a finite verb in Czech has been used as a counterpart of the infinitive in English, which only underlines the "more verbal nature" of English discussed at the beginning of this article. 
She sorted through both very quickly, knowing exactly what she wanted and what was to be left for-or at least with - the hospital. [14]

I seem to recall being mystified, an infantile anthropologist among the anthropophagi. [18]
Obojí jen zběžně prohrábla, protože věděla naprosto presně, co si chce nechat a co ponechá nemocnici-nebo prostě v nemocnici. [15]

Matně si vybavuju, že mě obloudili, byl jsem jako infantilní antropolog mezi antropofágy. [19]

\subsection{The Remaining Functions}

The remaining two functions of the infinitive have been significantly less frequent than the previously discussed ones and, moreover, neither of them has been found in all the four books. The infinitive functioning as a subject has been found in two books (Harding [16] and Mitchel [20]) and the infinitive function as a comment has been found only in Harding [16] and only in one particular part of the book - all the four cases appearing on two subsequent pages.

How like grown-ups it is to see danger where there is none; to look for it in a lake or a well, which offer no harm in themselves without the agency of human malevolence or neglect. [16]

Exceeding well worded, to speak plain. [16]
To jsou celí dospělí, vidí nebezpeči tam, kde žádné není, hledaji ho ve studni či v jezeře, kde bez pričiněni lidské zlovolnosti či nedbalosti nic nehrozí. [17]

Nadobyčej slovná, mám-li hovořit upřímně. [17]

As for the comments, the translation by means of embedded clauses has been expected. The translation of the infinitive in the function of a subject by means of a finite verb corresponded to the "verbal nature" of Czech discussed above.

\section{Conclusion}

The aim of this article was to offer an insight into the distribution of the different functions of the infinitive in contemporary English fiction and their corresponding translations into Czech. The most frequently used non-finite form was the participle, if both the present and past forms were treated together. If taken separately, then it has been the infinitive which has occurred with the highest frequency, followed by the present and past participle and with the gerund being generally the least frequent. A really surprising finding has been the low frequency of more complex non-finite forms. In the whole corpus there were no cases of the perfect forms (this included not only the infinitive, but gerund and participle forms as well), no progressive infinitives and only four cases of the passive infinitive. As regards the functions which the infinitive forms fulfilled, the infinitive as an adverbial has been the most frequent (apart from the infinitive functioning as an object which has been left out from the further analysis). It has also been a function with the most predictable / the most closely corresponding way of translation. In $70 \%$ of cases it has been translated by means of a subordinate adverbial clause of purpose. The following most common way of translation has been by means of a main clause. This solution has been applied in the cases where the action in the original main clause and the purpose expressed by the infinitive in fact represented two subsequent actions. The second most frequent function has been a postmodification of a noun where the two most common ways of translation have been by the infinitive or a relative clause. However more than $36 \%$ of the translations represented alternative solutions, e.g. an appositive clause, the infinitive form of a different verb, or the infinitive form in the source text has not been translated into Czech at all. The other functions found in the corpus have been considerably 
less frequent and their corresponding translations have generally been much less established, resulting in a wider range of different solutions.

The whole study has been performed with our students in mind. The corpus, or rather selected sentences are directly applicable in lessons as means of demonstrating the range of possible translations and mainly the fact that even for structures where there might seem to exist a clear solution, there might be more natural/suitable alternatives. When used in lessons, the authentic excerpts gathered can contribute to students' increased awareness of the different means at users' disposal caused by the differences between the languages. Further research into the frequency of more complex verb phrases by means of a corpus should reveal how frequent these forms (mainly perfect forms) actually are and subsequently how much students of English should focus on them as they often represent a real challenge.

\section{Acknowledgements}

This research has been supported by the Student Grant Competition of FP TUL, SGS 21169.

\section{Literature}

[1] BIBER et al.: Longman Grammar of Spoken and Written English. Longman, 1999. ISBN 0-582-23725-4.

[2] BIBER, D.; GRAY, B.: Challenging Stereotypes about Academic Writing: Complexity, Elaboration, Explicitness. Journal of English for Academic Purposes. 2010, Vol. 9, Issue 1, pp. 2-20. Orlando, Elsevier. DOI: 10.1016/j.jeap.2010.01.001

[3] BOWIE, J.; AARTS, B.: Change in the English infinitival perfect construction. In: Terttu Nevalainen and Elizabeth Closs Traugott (eds.), The Oxford handbook of the history of English. 2012, pp. 200-210. Oxford, New York, Oxford University Press, 2012. ISBN 978-0199922765. DOI: 10.1093/oxfordhb/9780199922765.013.0019

[4] BRINTON, L. J.; BRINTON, D. M.: The Linguistic Structure of Modern English. $2^{\text {nd }}$ edition. John Benjamins Publishing Company, 2010. ISBN 978-9027211729.

[5] CARTER, R.; McCARTHY, M.: Cambridge Grammar of English. Cambridge University Press, 2006. ISBN 978-0-521-58845-4 (Network CD ROM), 978-0-52158846-1 (Paperback).

[6] DUŠKOVÁ, L.: Mluvnice současné angličtiny na pozadí češtiny. Praha, Academia, 1994. ISBN 80-200-0486-6.

[7] DVOŘÁK, E.: Ke kodifikaci pravidel užívání přechodníků. Naše řeč. 1983, Vol. 66, Issue 4, pp. 180-192. ISSN 0027-8203.

[8] HORNOVÁ, L.: Syntactic functions of non-finite verb forms in a learner corpus of Czech students in Communication across Genres and Discourses. In: Proceedings of the Sixth Brno Conference on Linguistics Studies in English. Masarykova univerzita v Brně 2015, pp. 45-58. ISBN 978-80-210-7922-9.

[9] LEECH, G.; SVARTVIK, J.: A Communicative Grammar of English. $3^{\text {rd }}$ edition. Routledge, 2003. ISBN 978-0582506336.

[10] MALÁ, M.: Changing Clause Types in Written English. In: Trušník, Roman, Gregory Jason Bell and Katarina Němčoková (eds), From Theory to Practice 2013: Proceedings of the Fifth International Conference on Anglophone Studies. Univerzita Tomáše Bati ve Zlíně, 2015. pp. 107-117. ISBN 978-80-7454-450-7. 
[11] MALÁ, M.: Notes on Norms and Usage of Finite/Non-Finite Predication in Written English. Brno Studies in English. 2013, Vol. 39, Issue 1, pp. 27-40. ISSN 0524-6881 (print), 1805-0867 (online). DOI: 10.5817/BSE2013-1-2

[12] QUIRK et al.: A Comprehensive Grammar of the English language. Longman, 1985. ISBN 0-582-51734-6

[13] VACHEK, J.: On the interplay of external and internal factors in the development of language. In: Jan Chovanec (ed.), Chapters from the history of Czech functional linguistics. 2014, pp. 64-77. ISBN 978-80-210-7483-5. Lingua. 1962, Vol. 11, pp. 433448. DOI: $10.1016 / 0024-3841(62) 90053-0$

[14] ENRIGHT, A.: The Gathering. London, Jonathan Cape, 2007. ISBN 978-0-224-078733.

[15] ENRIGHT, A.: Shledání. Translated by Dominika Křest’anová. Praha, Odeon, 2009. ISBN 978-80-207-1298-1.

[16] HARDING, J.: Florence and Giles. London, Blue Door, 2010. ISBN 9780007315031.

[17] HARDING, J.: Florence a Giles. Translated by Čeněk Matocha. Praha, Plus, 2012. ISBN 978-80-259-0124-3.

[18] BARNES, J.: Nothing to be Frightened of. London, Vintage Books, 2009. ISBN 978-009-952374-1.

[19] BARNES, J.: Žádný důvod k obavám. Translated by Petr Fantys. Praha, Odeon, 2009. ISBN 978-80-207-1310-0.

[20] MITCHELL, D.: The Thousand Autumns of Jacob de Zoet. London: Sceptre, 2011. ISBN 978-0-340-92158-6.

[21] MITCHELL, D.: Tisíc podzimů Jacoba de Zoeta. Translated by Petra Diestlerová. Praha: Mladá fronta, 2013. ISBN 978-80-204-2668-0.

Mgr. Renata Šimůnková, Ph.D. 


\section{INFINITIV V ANGLIČTINĚ A JEHO PŘEKLADY DO ČEŠTINY}

Jeden ze zásadních rozdílů mezi angličtinou a češtinou spočívá $\mathrm{v}$ tom, že $\mathrm{v}$ anglické větě často dochází ke kondenzaci pomocí nominálních forem. Současné výzkumy navíc ukazují, že se jedná o jazykovou oblast, která $\mathrm{v}$ obou jazycích prochází vývojem, $\mathrm{v}$ jehož dủsledku se zmíněné rozdíly ještě dále zvětšují. Článek představuje výsledky srovnávací studie neurčitých slovesných frází ve formě infinitivu v angličtině a jejich odpovídajících překladů v češtině. Nejfrekventovanějšími funkcemi infinitivu byly funkce gramatického předmětu a infinitivu účelu, které byly následovány postmodifikací podstatného nebo př́́davného jména a infinitivem po sponovém slovese. Nejtěsněji korespondující překladová varianta se vázala k infinitivu účelu, který byl v 70 procentech výskytů přeložen pomocí vedlejší věty př́slovečné účelové.

\section{DER ENGLISCHE INFINITIV UND SEINE ÜBERSETZUNGEN INS TSCHECHISCHE}

Einer der grundlegenden Unterschiede zwischen der englischen und der tschechischen Sprache liegt darin, dass englische Sätze häufig durch Nominalgruppen kondensiert werden. Die gegenwärtigen Untersuchungen zeigen überdies, dass es sich in beiden Sprachen um ein ständig entwickelndes Sprachgebiet handelt, in dessen Folge die erwähnten Unterschiede noch weiter zunehmen. Dieser Artikel stellt die Ergebnisse einer Vergleichsstudie über infinite Verbphrasen in der Form des Infinitivs im Englischen und deren entsprechenden Übersetzungen im Tschechischen dar. Als häufigste Infinitivfunktionen treten die Funktionen der grammatikalischen Ergänzung und des Zweckinfinitivs auf, gefolgt von Postmodifikation des Substantivs oder Adjektivs und dem Infinitiv nach dem Kopulaverb. Die am besten übereinstimmende Übersetzungsvariante war mit dem Zweckinfinitiv verbunden, der in 70 Prozent der Vorkommen mit einem untergeordneten Finalsatz übersetzt wird.

\section{BEZOKOLICZNIK W JĘZYKU ANGIELSKIM I JEGO TŁUMACZENIA NA JĘZYK CZESKI}

Jedna $\mathrm{z}$ zasadniczych różnic pomiędzy językiem angielskim i czeskim twi $\mathrm{w}$ tym, że w zdaniach angielskich często dochodzi do kondensacji z użyciem form nominalnych. Ponadto współczesne badania pokazują, iż w tym obszarze oba języki przechodzą ewolucję, w wyniku której wspomniane różnice pogłębiają się jeszcze bardziej. Artykuł przedstawia wyniki studium porównawczego bezosobowych fraz czasownikowych $\mathrm{w}$ formie bezokolicznika $\mathrm{w}$ języku angielskim i ich thumaczeń w języku czeskim. Okazało się, że bezokolicznik najczęściej pełni funkcję dopełnienia oraz funkcję bezokolicznika celu, w następnej kolejności występuje postmodyfikacja rzeczownika lub przymiotnika i bezokolicznik po czasownikach łącznikowych. Najbardziej precyzyjny wariant tłumaczeniowy związany był z bezokolicznikiem celu, który w 70 procentach przypadków został przetłumaczony za pomocą zdania podrzędnego okolicznikowego celu. 